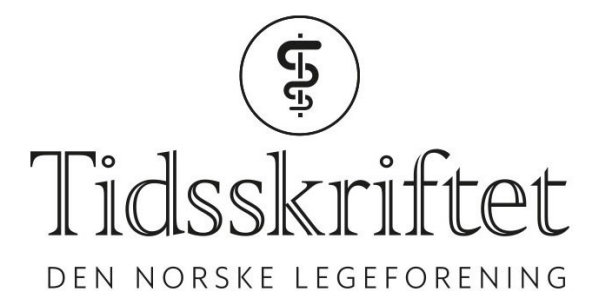

DEN NORSKE LEGEFORENING

\title{
Gjennomarbeidet lærebok i anatomi
}

ANMELDELSER

PER BRODAL

Professor emeritus, Institutt for medisinske basalfag

Universitetet i Oslo

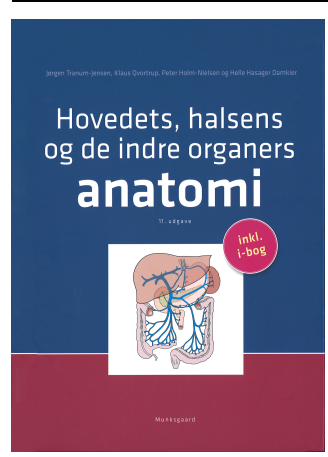

Jørgen Tranum-Jensen, Klaus Qvortrup, Peter Holm-Nilsen et al.

Hovedets, halsens og de indre organers anatomi

464 s, ill. København: Munksgaard, 2017. Pris DKK 995

ISBN 978-87-628-1559-9

Dette er 11. utgave av danske klassikere, nemlig Erik Andreassens De indre organers anatomi og Bevagelsesapparatets anatomi. Mye har imidlertid skjedd siden de først kom i 1950-60-årene. Den foreliggende boken omhandler både hodets og innvollenes anatomi. Med boken følger adgang til en nettversjon i PDF-format. Der finnes det lenker til videofilmer av kliniske undersøkelser (for eksempel laparoskopier). Målgruppene er lege- og tannlegestudenter.

Kapittel 1 omhandler kortfattet prinsipper for beskrivelse av organer og kliniske undersøkelsesmetoder (inklusive bildemodaliteter). Kapittel 2 gir en konsis oversikt over det autonome nervesystemet, som er viktig for å få utbytte av de kommende kapitlene. De neste 180 sidene (kapitlene 3-14) omhandler hodets anatomi, mens de neste vel 200 sidene omhandler brysthulen og bukhulen med tilhørende organer. Til sammen er det 31 kapitler. Til slutt er det en liste med forklaring av eponymer som er nevnt i boken og et fyldig stikkordregister.

Kapitlene er systematisk oppbygd, med en forholdsvis detaljert beskrivelse av strukturene fulgt av deres nerve- og blodforsyning. Relevant embryologi og kliniske poenger er presentert i egne bokser underveis, mens funksjonelle poenger er integrert i teksten. Betydningen av og opprinnelsen til mange latinske navn er forklart i fotnoter.

En særlig kvalitet ved denne boken er illustrasjonene. Det ligger åpenbart en didaktisk 
tanke bak hver enkelt figur ved at den viser utvalgte strukturer så forenklet at man raskt får tak i poengene. For øvrig er layouten prisverdig enkel og oversiktlig og bidrar til at det er lett å finne frem.

Det er ingen form for sammendrag eller fremheving av hovedpunkter. For meg er ikke det noen vesentlig innvending - sammendrag av anatomi blir lett bare en oppramsing av navn. Jeg stusser mer over at det ikke finnes noen henvisning til litteratur som forfatterne har benyttet under utarbeidingen. Både tekst og illustrasjoner bygger tross alt på andres arbeid, og selv innen anatomien er ikke all kunnskap hugget i sten.

Samlet er dette en meget god og gjennomarbeidet presentasjon av en viktig del av anatomien. Ikke minst bidrar figurene til å lette tilegnelsen. Anbefales både for legestudenter og klinikere som ønsker oppfrisking av relevante deler av anatomien.

Publisert: 2. oktober 2017. Tidsskr Nor Legeforen. DOI: 10.4045/tidsskr.17.0515

(C) Tidsskrift for Den norske legeforening 2020. Lastet ned fra tidsskriftet.no 